\title{
Effect of scots pine forest management on soil properties and carabid beetle occurrence under post-fire environmental conditions - a case study from Central Europe
}

\author{
Ewa Błońska', Bartłomiej Bednarz ${ }^{2}$, Magdalena Kacprzyk ${ }^{2 *}$, Wojciech Piaszczyk ${ }^{1}$ and Jarosław Lasota ${ }^{1}$
}

\begin{abstract}
Background: Fires have a fundamental impact on phytocoenoses and, depending on the size of the fire, can have a positive or negative effect. The role of fires in the formation of the species composition of plants, restoration of stands and changes in soil properties is well studied. However, the long-term relationship between forest management methods, soil properties and epigeic entomofauna assemblages in post-fire areas is still not clear. The effects of Scots pine stand management methods on biochemical soil properties and ground beetle assemblages in the largest post-fire area in Central Europe after the second World were investigated. The study was conducted in the Rudy Raciborskie Forest district in southern Poland. The soil properties and epigeic beetle community structure were analysed. The research covered areas with natural and artificial pine regeneration, which were subjected to various care treatments.
\end{abstract}

Results: The tendency for higher accumulations of organic matter in the soil of stands that underwent natural regeneration was proven. The stimulating role of soil organic carbon on the activity of dehydrogenases in the soil of naturally renewed areas with silvicultural treatment (NRAT) was noted. Regardless of the manner of stand regeneration, the activity of $\beta$-glucosidase was higher in the areas in which breeding treatments were practised. Furthermore, managed forest stands presented a higher abundance of carabid beetles than stands without treatment practices. Thirteen epigeic beetle species from the families Geotrupidae, Carabidae, Curculionidae, Cerambycidae and Silphidae were captured, with beetles from the first two families being the most numerous. Rare epigeal carabid species in the fauna of Poland and Europe, such as Carabus glabratus (Paykull) and Carabus auronitens Fabr., found appropriate habitat conditions for survival in the post-fire areas. Compared with the other areas, in the NRAT area, there were better stand and soil properties and more features conducive to epigeic entomofaunal occurrences. The highest post-fire content of polycyclic aromatic hydrocarbons was recorded in the soils of the sites that underwent artificial regeneration. The results suggest that preparing the soil before the introduction of new vegetation affects the amount of aromatic hydrocarbons (PAHs).

(Continued on next page)

\footnotetext{
* Correspondence: magdalena.kacprzyk@urk.edu.pl

${ }^{2}$ Department of Forest Ecosystems Protection, Faculty of Forestry, University

of Agriculture in Krakow, Al. 29-go Listopada 46, 31-425 Kraków, Poland

Full list of author information is available at the end of the article
}

\section{Springer Open}

( ) The Author(s). 2020 Open Access This article is licensed under a Creative Commons Attribution 4.0 International License, which permits use, sharing, adaptation, distribution and reproduction in any medium or format, as long as you give appropriate credit to the original author(s) and the source, provide a link to the Creative Commons licence, and indicate if changes were made. The images or other third party material in this article are included in the article's Creative Commons licence, unless indicated otherwise in a credit line to the material. If material is not included in the article's Creative Commons licence and your intended use is not permitted by statutory regulation or exceeds the permitted use, you will need to obtain permission directly from the copyright holder. To view a copy of this licence, visit http://creativecommons.org/licenses/by/4.0/. 
(Continued from previous page)

Conclusions: The better performance of the NRAT stand draws attention to the positive aspects of the use of natural regeneration, both from ecological and economic perspectives. The effects of forest management on the amount of soil organic matter after fires have been proven. The natural regeneration of stands was conducive to the accumulation of organic matter. The enzymatic activity of soils is influenced by the renewal method and forest management strategy. The NRAT area was characterized by the highest number of carabid species.

Keywords: Stand treatment strategy, Forest regeneration, Enzyme activity, Soil organic carbon, Epigeic beetle assemblage structure

\section{Background}

Poland is situated in the area of Europe that is endangered by forest fires, which are primarily connected with its geographic location between the contrasting oceanic and continental climates (Kundzewicz and Matczak 2012). It is also characterized by permanent factors influencing the water balance, such as precipitation and cyclical long-term droughts, leading to reductions in groundwater (Kubicz et al. 2019). The fully biocenotic conditions of the forests and their uniform age and species structure make them particularly vulnerable to fires (Ubysz et al. 2006; Szczygieł 2012). According to the European Forest Fire Information System, Poland ranks third (after Portugal and Spain) in the average annual number of fires and eighth in the area covered by fires (Szczygieł 2012). The role of fires in the formation of the species composition of woody plants, restoration of stands and changes in soil properties have been widely studied (Martìnez-Sánchez et al. 1999; González-Pérez et al. 2004; Certini 2005; Knicker 2007; Homann et al. 2011; Verma and Jayakumar 2012; Barros et al. 2018; Stoddard et al. 2018). Many studies have also demonstrated either the negative or the positive effects of forest fires on carabid beetle assemblages (Holliday 1991; Beaudry et al. 1997; Wikars 1997; Gongalsky et al. 2006) and their biomass (Skłodowski 1994). Carabid beetles can play an important role as bioindicators of ecological soil productivity and disturbance in forest biocenoses because their biomass is strongly and positively related to the biomass of the macrofauna responsible for litter decomposition (Koivula 2011). Nevertheless, this phenomenon is usually analysed in the time soon after disturbances. Most often, after a fire, there is a temporary increase in soil fertility; however, after a few years, most of the nutrients available to the plants released from the fire are washed out, and ultimately, the fire contributes to the sterilization of the soil (Pritchett and Fisher 1987; Brais et al. 2000). After fires, the biological activity of soil decreases (Xue et al. 2014); in extreme cases, forest fires can lead to soil sterilization (Certini 2005). The reconstitution of microbial communities in forest soils after fires is a long-term process and depends to a great extent on the post-fire management strategy (Hawryś et al. 1998; Kazakevič et al. 1998). The method of post-fire treatment indirectly influences the shaping of the physical, chemical and biochemical soil properties (DeBano et al. 1998; Kaczmarek et al. 2004; Dziadowiec 2010; Gonet 2010; Francos et al. 2018). The effects of forest management practices on the composition of ground-dwelling beetle communities has also been reported (Lange et al. 2014; Skłodowski et al. 2018).

A forest fire in the Rudy Raciborskie, Rudziniec and Kędzierzyn Forest Districts in southern Poland was the largest fire in post-war Europe (FAO 1998; Piwnicki and Ubysz 2004). As a result of the fire, which occurred in 1992, the forests covering an area of approximately 10 thousand hectares were destroyed. The aim of this study was to evaluate the effect of forest management practices on epigeic entomofauna assemblages and the biochemical properties of post-fire soils 23 years after this event. The research included areas with natural and artificial Scots pine regeneration, which were subjected to various silvicultural treatments. From the perspective of postfire economic and ecological measures, this issue is particularly important for the regeneration of productivity and biological diversity of habitats. The following hypotheses were tested: 1) the method of stand renewal and subsequent treatments carried out in pine stands determine the soil conditions, which consequently results in differences in the accumulation of soil organic matter and enzymatic activity; 2) in the post-fire stands that underwent natural regeneration without treatment, the abundance of ground beetle species reaches higher values than it does in the managed stands; and 3) the amount of polycyclic aromatic hydrocarbons in the soil is linked to the forest management strategy.

\section{Materials and methods}

\section{Study area and experimental design}

The study was conducted in the Rudy Raciborskie Forest district in southern Poland $\left(50^{\circ} 13^{\prime} 44.2^{\prime \prime} \mathrm{N}, 18^{\circ} 27^{\prime}\right.$ 20.0" E) (Fig. 1). The mean air temperature in the studied plot is $8.5^{\circ} \mathrm{C}$, the vegetation growth period lasts from 220 to 230 days, and the annual rainfall is 


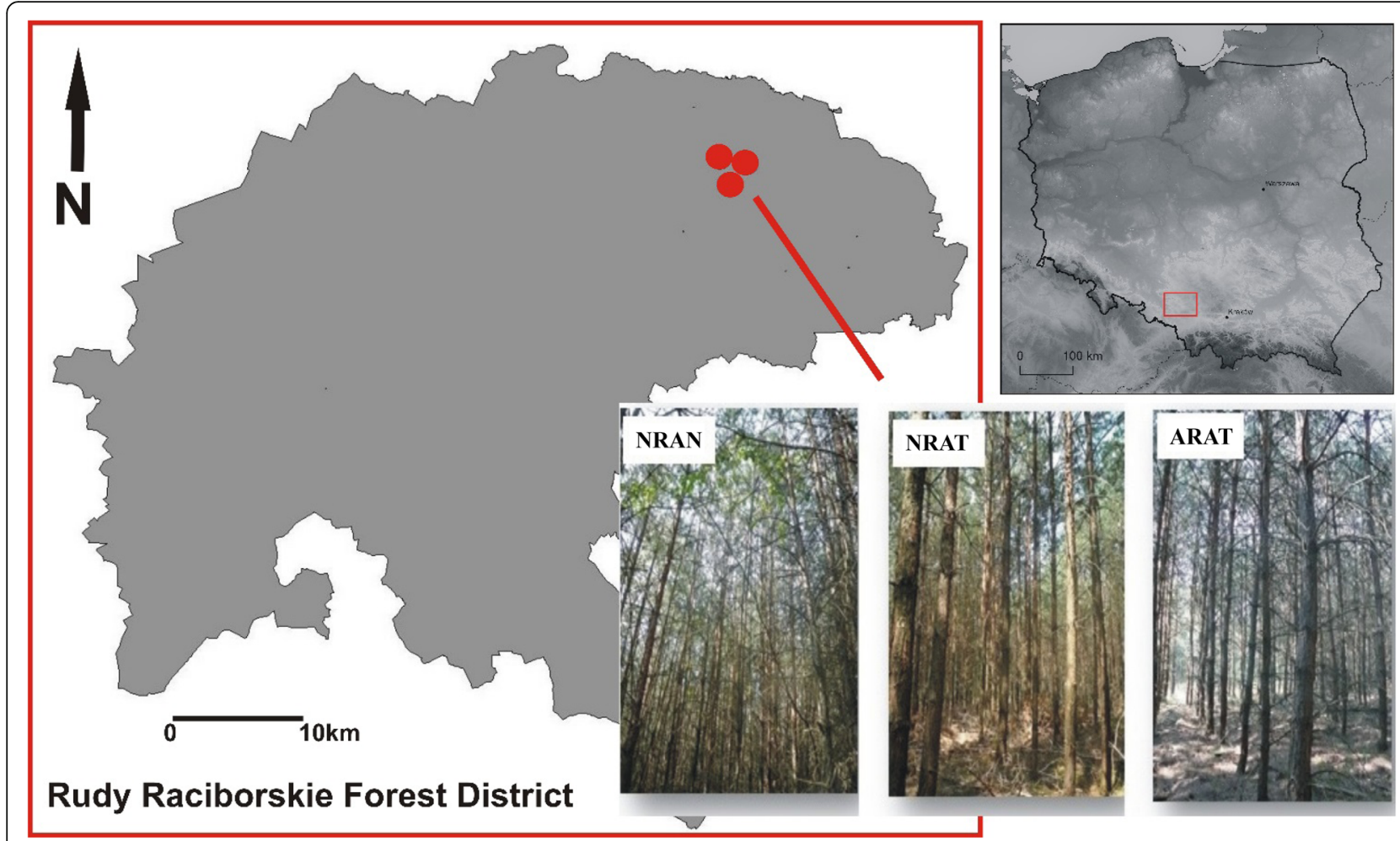

Fig. 1 Study plots sampling design in varius silvicultural treatments

approximately 630-650 mm (Operat siedliskowy dla Nadleśnictwa Rudy Raciborskie 2005). Podzols were predominant in the study area, constituting approximately $90 \%$ of the soil surface, while cambisols with brunic arenosols accounted for $10 \%$. The dominant species is Scots pine, which occupies approximately $75 \%$ of the forest area (Operat siedliskowy dla Nadleśnictwa Rudy Raciborskie 2005). In the first half of June 2015, three 22-year-old P. sylvestris stands were selected for study. In each forest stand, 10 circular study plots with radii of $5.64 \mathrm{~m}$ and an area of 1 acre were established (in total, the tests were carried out at 30 study areas). The first group of study plots represented pine stands originating from natural regeneration with no previously performed silvicultural treatment (naturally renewed area with no treatment-NRAN). The second group of study plots represented pine stands originating from natural regeneration in an area where early and late clearings were performed in 2006 and 2015 (naturally renewed area with treatment-NRAT). In the third group of study plots, after burning, the stand was artificially regenerated with ploughed furrows for soil cultivation. In this stand, early and late clearings were carried out in two sequences, i.e., in 2007 and 2014 (artificial renewed area with treatment-ARAT). The research plots were established in areas dominated by Leucobryo-Pinetum communities. Vaccinium myrtillus,
Deschampsia flexuosa, Dryopteris carthusiana, Pleurozium schreberi, Dicranum undulatum and Leucobryum glaucum were the dominant species in the undergrowth.

\section{Measurements of stand biometric parameters}

A complete inventory of all the living trees was conducted on each study plot. For each tree, the diameter at breast height (dbh) was measured with an accuracy of $0.5 \mathrm{~cm}$. The height $(H)$ of 30 randomly selected trees was evaluated with an accuracy of $0.1 \mathrm{~m}$. On the basis of the measured $\mathrm{dbh}$ for each tree, the basal area $(G)$ was calculated. To obtain the heights of all the tested trees, a tree height model was prepared for each study area of the stand. Based on the data collected from the particular study areas of the stand ( $n=300$ for each study area), height curves were created. Using the logarithmic function of the trend line, the heights of all the remaining trees within the study area were calculated. The volume of the trees that exceeded the threshold dbh measurement $(7 \mathrm{~cm})$ was established based on Scots pine timber volume tables for standing trees (Ochał 1999). Then, the stand form factor $(f)$ was expressed as the ratio of the tree thickness to the basal area of the trunk, and the height of the tree was determined. Finally, for each study area, a stand form factor model was created, enabling the use of the polynomial function of the trend line, and 
the index value for the rest of the trees was determined. With the stand form factor, the thickness of the remaining trees was calculated. The slenderness coefficient $(S)$ of the trees was calculated as the ratio of the height to the dbh.

\section{Soil sampling and analysis}

The test area covered by the soil sampling was dominated by Haplic Podzols. Soil samples for laboratory analysis were collected from the surface horizons, from a depth of $0-15 \mathrm{~cm}$ (Fig. 2), after removing the organic layers. From each group of study plots, 10 soil samples were taken for laboratory analysis, and each sample was a mixture of 5 replicates. The texture was determined using laser diffraction (Analysette 22, Fritsch, IdarOberstein, Germany), the $\mathrm{pH}$ was analysed using the

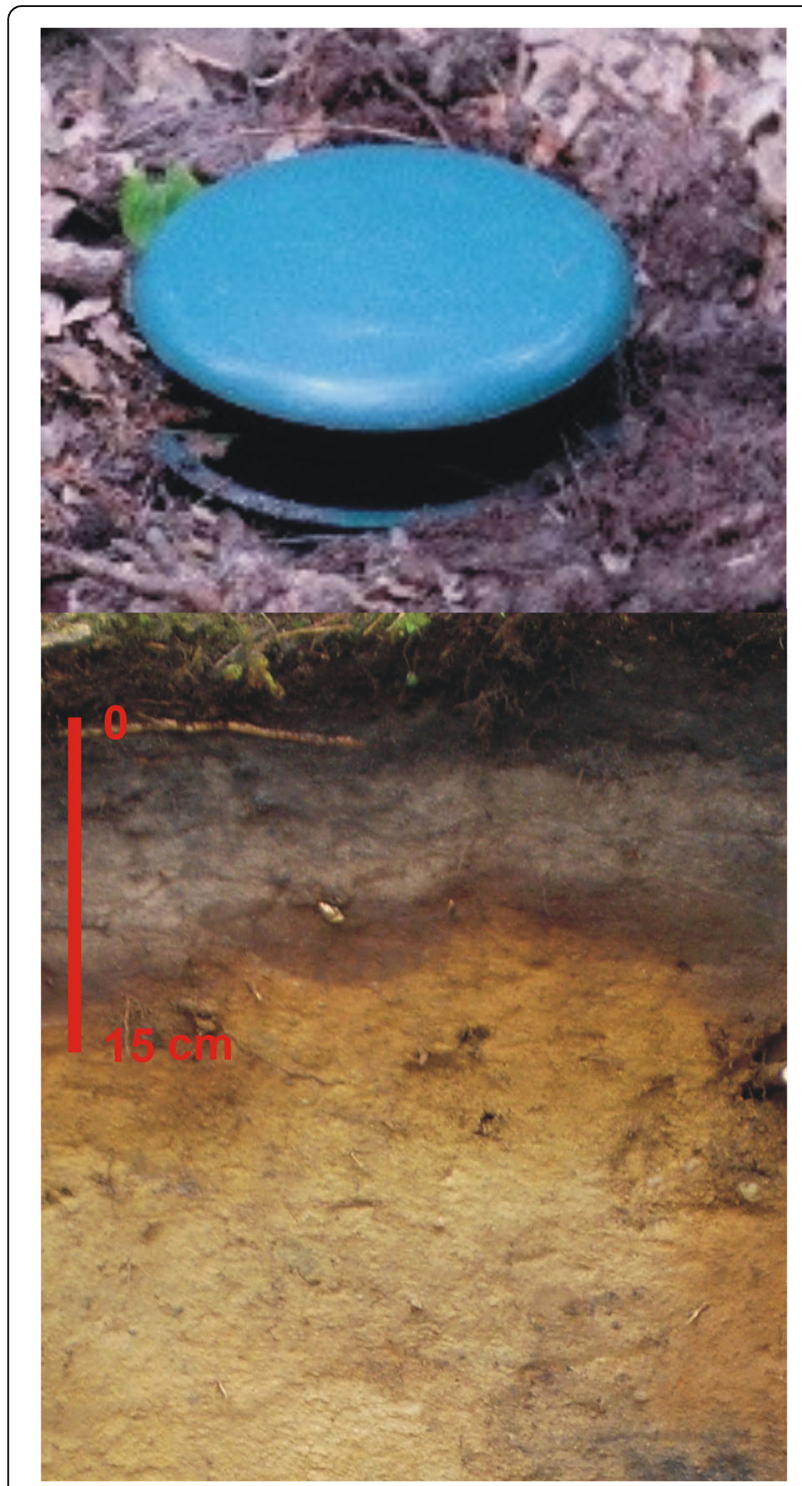

Fig. 2 Soil sampling and trap scheme potentiometric method, and the total nitrogen $(\mathrm{N})$ and organic carbon $\left(C_{t}\right)$ contents were measured using a Leco CNS True Mac Analyser (Leco, St. Joseph, MI, USA). The exchangeable aluminium (Al) was determined by the Sokołow method, and hydrolytic acidity was determined by the Kappen method. The concentration of cations was determined by ICP (ICP-OES Thermo iCAP 6500 DUO, Thermo Fisher Scientific, Cambridge, U.K.). Using Lenhard's method based on Casida's procedure, dehydrogenase activity (DH) was determined (Alef and Nannipieri 1995). To determine the activity of $\beta$-glucosidase (BG), the method of Eivazi and Tabatabai (1990) was used. The PAHs were analysed with the HPLC method (Błońska et al. 2016a).

\section{Epigeic beetle control and community structure analysis}

The occurrence of ground beetles was monitored from 30 June to 1 October 2015 using Barber pitfall traps $(9 \mathrm{~cm}$ in diameter and $0.5 \mathrm{~L}$ capacity; Fig. 2) containing a fluid preservative (ethylene glycol). In each type of study site, five individual pitfall traps were located in every second trial plot and were placed near a tube that snapped into the centre of the plot surface. The traps were dug into the ground to a depth that allowed the upper edge of the container to rest at ground level. Insect control was carried out at biweekly intervals. The beetle specimens collected from the traps were identified to the species level with the keys from Trautner and Geigenmüller (1987), Hůrka (1996) and Klausnitzer (2005). The beetle assemblages were analysed using individual dominance indices to reflect the percentage of particular beetle species in the pool of all the insects collected at a given study site. To compare the forest biocenoses, the Simpson dominance index (c) (Simpson 1949), the Shannon-Wiener diversity index $\left(H^{\prime}\right)$ (Shannon and Weaver 1948) and the Simpson diversity index $(D)$ (Simpson 1949) were used. Moreover, for carabid beetles, ecological features (Burakowski et al. 1974; Hůrka 1996) were determined. We divided the beetles into 1) trophic groups: large zoophages with a body length above $15 \mathrm{~mm}$, small zoophages with a body length below $15 \mathrm{~mm}$ and hemizoophages (omnivorous species); 2) ecological groups: forest, eurytopic and open areas species; and 3) geographical groups: palearctic, holarctic and European species (Skłodowski and Garbalińska 2007).

Based on carabid humidity preferences, we distinguished 1) hygrophilous species, whose occurrence is related to the proximity of water, 2) mesophilic species, which are typical of areas presenting moderate soil moisture, and 3) xerophilic species, which are characterized by low water requirements. The scientific names of the insects were assigned according to de Jong et al. (2014). 


\section{Statistical analysis}

One-way analysis of variance (ANOVA) was used to compare characteristics between the different forest management areas. The results of the ANOVA were assessed with a Shapiro-Wilk's normality test, Bartlett's test of homogeneity of variances and Fligner-Killeen's test of homogeneity of variances. Tukey's HSD multiple comparison tests were used in the post hoc analysis. The effect of forest management practices and the type of regeneration on epigeic beetle abundance was analysed using a Mann-Whitney $U$ test. Principal component analysis (PCA) was used to evaluate the relationships between the chemical properties, enzymatic activity of the soil and type of forest management. The effects of soil properties and forest management on enzyme activity was analysed by a generalized linear model (GLM). The statistical significance of the results was verified at the $\alpha=0.05$ significance level. All the necessary analyses were performed in the $\mathrm{R}$ programming language (version 3.3.3), $\mathrm{R}$ studio (version 1.0.136) ( $\mathrm{R}$ Development Core Team 2017) and (Statistica 10 software 2010).

\section{Results}

\section{Characterization of the stands}

The biometric parameters of the studied stands under the examined management techniques differed significantly. The pine trees in the NRAT area were characterized by the highest $\mathrm{dbh}(10.76 \mathrm{~cm})$ and volume $\left(0.0494 \mathrm{~m}^{3}\right)$, while the trees in the NRAN area were characterized by the lowest $\mathrm{dbh}(4.29 \mathrm{~cm})$ and volume $\left(0.0027 \mathrm{~m}^{3}\right)$. Statistically significant differences in the slenderness coefficient between management techniques were also observed. The trees in the NRAN area were characterized by a higher ratio of slenderness, nearly $41 \%$ and $45 \%$ higher than those in the NRAT and ARAT areas, respectively (Table 1). The most distinguishing differences between the analysed stand characteristics were observed between the ARAT and NRAN areas (Table 2).
Table 2 Results of one-way analysis of variance (ANOVA) and Tukey's HSD test for the relation between study plots and growth parameters of the stand

\begin{tabular}{|c|c|c|c|c|}
\hline \multirow{2}{*}{$\begin{array}{l}\text { Variant of } \\
\text { area } \\
\text { management }\end{array}$} & \multicolumn{4}{|l|}{$P$ value } \\
\hline & $\bar{V}$ & $\mathrm{dbh}$ & $H$ & $S$ \\
\hline NRAT- NRAN & 0.0000 & 0.0000 & 0.3053 & 0.0000 \\
\hline ARAT-NRAN & 0.0000 & 0.0000 & 0.0024 & 0.0000 \\
\hline ARAT-NRAT & 0.0034 & 0.0401 & 0.1612 & 0.0430 \\
\hline
\end{tabular}

Values in bold are statistically different $(p<0.05)$, volume $\left(V, \mathrm{~m}^{3}\right)$; diameter at breast height $(\mathrm{dbh}, \mathrm{cm})$; Lorey height $(H, \mathrm{~m})$; slenderness coefficient $(S)$

\section{Soil properties}

In the studied soils, the sand fraction was dominant; its content varied from $88 \%$ to $99 \%$ depending on the study area. A small amount of silt and clay was present. There were no statistically significant differences in texture among the selected study areas (Table 3). The highest average organic carbon (5.17\%) and nitrogen (0.25\%) contents were recorded in the soil of the NRAT area (Table 3). The lowest contents of carbon (3.86\%) and nitrogen $(0.19 \%)$ were found in the soil of the ARAT area (Table 3$)$. There were no statistically significant differences in the carbon content between the study areas. The soil of each study area was characterized by similar organic matter decomposition rates, expressed as the $\mathrm{C} /$ $\mathrm{N}$ ratio. A lower $\mathrm{pH}$ was noted in the soils of the NRAT area than in the soils of the other study areas (Table 3). There were no statistically significant differences in the base cation content (BC) between the study areas. The $\beta$-glucosidase and dehydrogenase activity varied among the soils of the study areas. The $\beta$-glucosidase activity was significantly lower in the soils of the NRAN area than in the soils of the ARAT and NRAT areas (Table 3 ). No statistically significant differences were found in the dehydrogenase activity of the soils from all the areas sampled.

The highest PAH concentration was recorded in the soils of the post-fire study area with artificial regeneration after soil preparation (Table 4). In the soils of this study area, 3-, 5- and 6-ring PAHs were recorded. The

Table 1 The mean ( \pm SD) values of examined features of trees in Scots pine stands in the study plots

\begin{tabular}{|c|c|c|c|c|c|c|}
\hline $\begin{array}{l}\text { Variant of the area } \\
\text { management }\end{array}$ & $N\left(\right.$ pcs.ha $\left.{ }^{-1}\right)$ & $\begin{array}{l}\text { Diameter at breast } \\
\text { height }(\mathrm{cm})\end{array}$ & Lorey height (m) & $\begin{array}{l}\text { Basal area } \\
\left(\mathrm{m}^{2} \cdot h a^{-1}\right)\end{array}$ & $\begin{array}{l}\text { Volume }\left(\mathrm{m}^{3}\right) \\
\text { Total volume }\left(\mathrm{m}^{3} \cdot \mathrm{ha}^{-1}\right)\end{array}$ & $\begin{array}{l}\text { Slenderness } \\
\text { coefficient }\end{array}$ \\
\hline \multirow[t]{2}{*}{ NRAN } & 21,440 & $4.29^{a} \pm 2.06$ & $7.70^{\mathrm{a}}$ & $39.43^{a}$ & $0.0027^{\mathrm{a}}$ & $203.62^{a}$ \\
\hline & & & & & 58.93 & \\
\hline \multirow[t]{2}{*}{ ARAT } & 3950 & $9.73^{b} \pm 3.31$ & $10.03^{b}$ & $32.76^{b}$ & $0.0346^{\mathrm{b}}$ & $112.31^{\mathrm{b}}$ \\
\hline & & & & & 136.73 & \\
\hline \multirow[t]{2}{*}{ NRAT } & 3010 & $10.76^{\mathrm{b}} \pm 2.38$ & $12.51^{\mathrm{c}}$ & $28.71^{b}$ & $0.0494^{b}$ & $120.72^{\mathrm{b}}$ \\
\hline & & & & & 148.76 & \\
\hline
\end{tabular}

${ }^{a}$ The total volume $(\mathrm{Vc})$ expressed as a volume sum of all trees at 10 circular trial plots per 1 ha, different small letters in the upper index of the mean values mean significant differences 
Table 3 Mean values and range of properties in soil of different study plots

\begin{tabular}{|c|c|c|c|c|c|c|c|c|c|}
\hline \multirow{2}{*}{$\begin{array}{l}\text { Characteristics } \\
\text { of soil }\end{array}$} & \multicolumn{3}{|l|}{ NRAN } & \multicolumn{3}{|l|}{ ARAT } & \multicolumn{3}{|l|}{ NRAT } \\
\hline & Mean & Min & Max & Mean & Min & Max & Mean & Min & Max \\
\hline$\overline{\mathrm{Ct}}$ & $4.83^{\mathrm{a}}$ & 3.00 & 6.41 & $3.86^{\mathrm{a}}$ & 1.71 & 8.38 & $5.17^{\mathrm{a}}$ & 2.34 & 7.80 \\
\hline $\mathrm{Nt}$ & $0.23^{\mathrm{a}}$ & 0.12 & 0.31 & $0.19^{\mathrm{a}}$ & 0.08 & 0.39 & $0.25^{\mathrm{a}}$ & 0.08 & 0.48 \\
\hline$C / N$ & $21.43^{\mathrm{a}}$ & 16.93 & 30.01 & $21.98^{\mathrm{a}}$ & 14.37 & 27.64 & $22.86^{\mathrm{a}}$ & 16.35 & 42.97 \\
\hline $\mathrm{pH} \mathrm{H} \mathrm{H}_{2} \mathrm{O}$ & $4.02^{\mathrm{a}}$ & 3.78 & 4.35 & $4.24^{\mathrm{a}}$ & 3.98 & 4.87 & $3.98^{b}$ & 3.73 & 4.40 \\
\hline $\mathrm{pH} \mathrm{KCl}$ & $3.20^{\mathrm{a}}$ & 2.98 & 3.50 & $3.38^{\mathrm{a}}$ & 3.14 & 3.79 & $3.17^{b}$ & 2.84 & 3.61 \\
\hline Y & $17.53^{\mathrm{a}}$ & 8.42 & 23.45 & $13.16^{\mathrm{a}}$ & 6.78 & 24.62 & $17.34^{\mathrm{a}}$ & 9.61 & 26.40 \\
\hline $\mathrm{Al}$ & $5.48^{\mathrm{ab}}$ & 3.06 & 7.09 & $4.14^{\mathrm{b}}$ & 1.37 & 8.47 & $6.62^{\mathrm{a}}$ & 3.75 & 8.51 \\
\hline $\mathrm{Ca}$ & $0.40^{\mathrm{a}}$ & 0.09 & 0.63 & $0.52^{\mathrm{a}}$ & 0.19 & 1.50 & $0.31^{\mathrm{a}}$ & 0.11 & 0.56 \\
\hline K & $0.19^{\mathrm{a}}$ & 0.06 & 0.34 & $0.09^{b}$ & 0.05 & 0.19 & $0.12^{a b}$ & 0.09 & 0.15 \\
\hline $\mathrm{Mg}$ & $0.10^{\mathrm{a}}$ & 0.03 & 0.17 & $0.06^{\mathrm{b}}$ & 0.04 & 0.11 & $0.05^{b}$ & 0.04 & 0.07 \\
\hline $\mathrm{Na}$ & $0.007^{\mathrm{a}}$ & 0.002 & 0.014 & $0.007^{\mathrm{a}}$ & 0.004 & 0.010 & $0.007^{\mathrm{a}}$ & 0.004 & 0.011 \\
\hline$P$ & $60.08^{\mathrm{a}}$ & 26.88 & 107.10 & $31.91^{\mathrm{a}}$ & 6.79 & 81.20 & $38.32^{a}$ & 7.07 & 93.10 \\
\hline$B C$ & $0.70^{\mathrm{a}}$ & 0.19 & 1.10 & $0.68^{\mathrm{a}}$ & 0.29 & 1.62 & $0.49^{\mathrm{a}}$ & 0.27 & 0.76 \\
\hline Sand & $95^{\mathrm{a}}$ & 90 & 98 & $96^{\mathrm{a}}$ & 92 & 99 & $94^{a}$ & 92 & 95 \\
\hline Silt & $4^{\mathrm{a}}$ & 2 & 8 & $3^{\mathrm{a}}$ & 1 & 6 & $5^{a}$ & 4 & 6 \\
\hline Clay & $1^{\mathrm{a}}$ & 0 & 2 & $1^{\mathrm{a}}$ & 0 & 3 & $1^{\mathrm{a}}$ & 0 & 1 \\
\hline $\mathrm{DH}$ & $14.88^{\mathrm{a}}$ & 2.37 & 28.12 & $11.69^{\mathrm{a}}$ & 3.20 & 20.15 & $9.44^{\mathrm{a}}$ & 2.95 & 13.45 \\
\hline$B G$ & $110.03^{b}$ & 54.52 & 161.25 & $309.97^{a}$ & 99.67 & 715.19 & $309.04^{a}$ & 140.66 & 592.76 \\
\hline
\end{tabular}

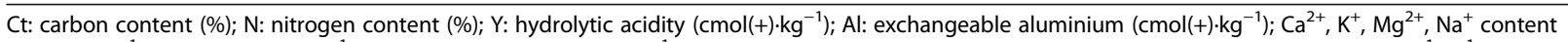
$\left(\mathrm{cmol}(+) \cdot \mathrm{kg}^{-1}\right) ; \mathrm{P}$ content $\left(\mathrm{mg} \cdot \mathrm{kg}^{-1}\right) ; \mathrm{BC}$ : base cations $\left(\mathrm{cmol}(+) \cdot \mathrm{kg}^{-1}\right)$; sand, silt and clay content $(\%) ; \mathrm{DH}$ : dehydrogenase activity $\left(\mu \mathrm{mol}\right.$ TPF $\left.\cdot \mathrm{kg}^{-1} \cdot \mathrm{h}^{-1}\right)$, BG: $\beta$-glucosidase activity ( $\left.\mathrm{mmol} \mathrm{pNP} \cdot \mathrm{kg}^{-1} \cdot \mathrm{h}^{-1}\right)$, different small letters in the upper index of the mean values mean significant differences

total concentration of PAHs in the soils of this study area was $4.923 \mu \mathrm{g} \cdot \mathrm{kg}^{-1}$. The highest concentrations were recorded for indene $(1,2,3-\mathrm{c}, \mathrm{d})$ pyrene and benzo $(\mathrm{g}, \mathrm{h}, \mathrm{i})$ perylene and benzo (b) fluoranthene, and their contents were 1225,1231 and $1066 \mu \mathrm{g} \cdot \mathrm{kg}^{-1}$, respectively. The soils of the other study areas were characterized by lower PAH contents. In the soils with natural regeneration, only fluorene, phenanthrene and benzo (a) anthracene were present. The total concentration of PAHs in the soils of the NRAN area was $0.784 \mu \mathrm{g} \cdot \mathrm{kg}^{-1}$, and in the soils of the NRAT area, the total PAH concentration was $0.462 \mu \mathrm{g} \cdot \mathrm{kg}^{-1}$ (Table 4).

The PCA confirmed the stimulating effect of carbon and nitrogen content on the enzymatic activity (Fig. 3). The two main factors had a significant impact (54.31\%) on the variance of the variables. Factor 1 relates to the carbon and nitrogen content. In factor 2, the factors that explain the most variation are associated with the forest management strategy. The soils of the ARAT area were associated with the highest $\mathrm{pH}$ and a relatively low carbon and nitrogen content. The soils of the NRAN area contained the most base cations. Based on the GLM analysis, a strong dependence of the enzymatic activity on the carbon content in the soils was observed (Table 5).

\section{Ground entomofauna assemblages}

During the field study, in the three stands subjected to various treatments, a total of 2573 specimens of ground beetles, representing 5 families, were found. Regardless of the study site type, Anoplotrupes stercorosus Scriba and Trypocopris vernalis (L.) were the most numerous insect species, together accounting for $72.5 \%$ and $75.7 \%$

Table 4 Polycyclic aromatic hydrocarbons $\left(\mu \mathrm{g} \cdot \mathrm{kg}^{-1}\right)$ in soil of different study plots

\begin{tabular}{|c|c|c|c|c|c|c|c|c|c|c|c|c|c|}
\hline Variant of the area management & Acy & Flu & Phe & Flt & Pyr & $\mathrm{BaA}$ & Chr & BkF & $\mathrm{BbF}$ & $\mathrm{BaP}$ & $\mathrm{IcdP}$ & BghiP & $\Sigma \mathrm{PAHS}$ \\
\hline NRAN & n.d. & n.d. & 0.289 & n.d. & n.d. & 0.495 & n.d. & n.d. & n.d. & n.d. & n.d. & n.d. & 0.784 \\
\hline ARAT & 0.053 & n.d. & 0.247 & n.d. & n.d. & n.d. & n.d. & 0.444 & 1.066 & 0.657 & 1.225 & 1.231 & 4.923 \\
\hline NRAT & n.d. & 0.173 & 0.298 & n.d. & n.d. & n.d. & n.d. & n.d. & n.d. & n.d. & n.d. & n.d. & 0.462 \\
\hline
\end{tabular}

acenaphtylen (Acy), fluoren (Flu), phenanthrene (Phe), fluoranthene (Flt), pyrene (Pyr), benzo(a) anthracene (BaA), chrysene (Chr), benzo(k), fluoranthene (BkF), benzo(b) fluoranthene (BbF), benzo(a) pyrene (BaP), indeno (1,2,3-c,d) pyren (IcdP), and benzo(g,h,i) perylene (BghiP); n.d. - no determined 


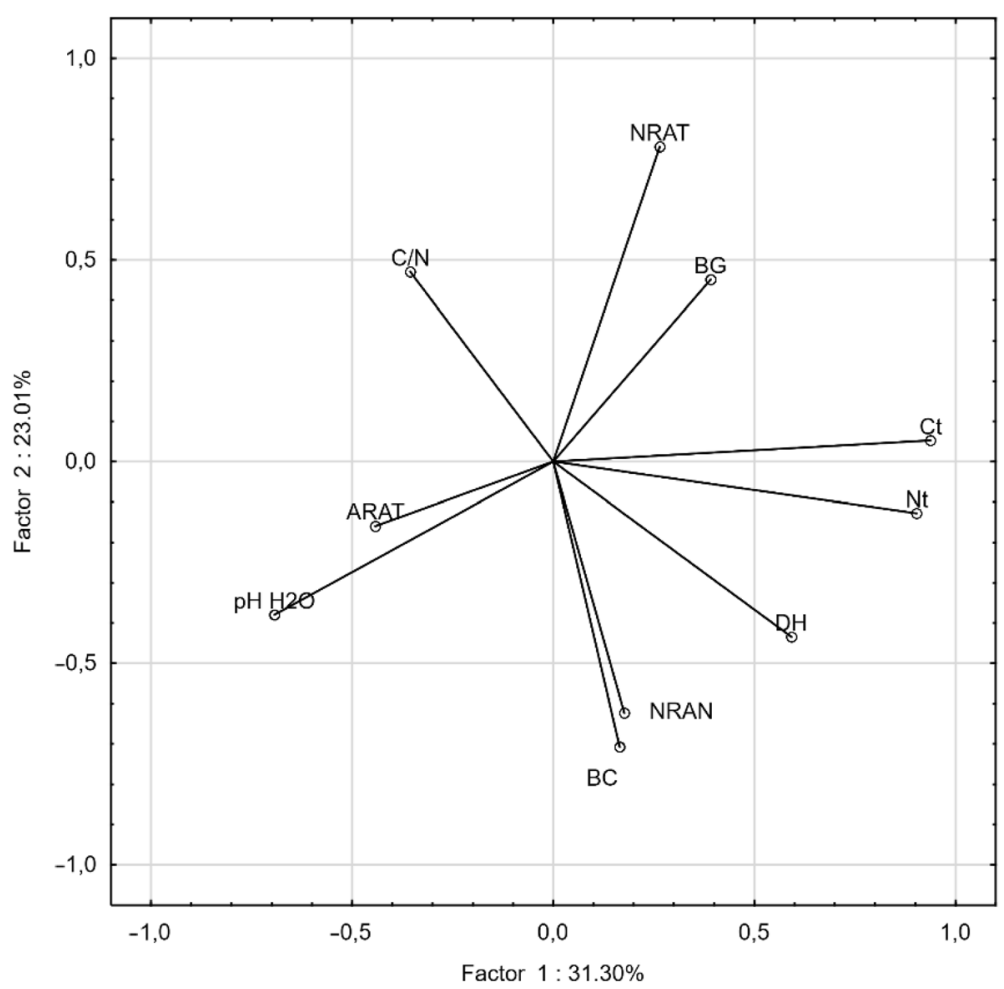

Fig. 3 Projection of the variables on the factor plane in the soil of the different study plots

of the total insect specimens caught in the NRAN and NRAT areas, respectively. Seven carabid species composed the second most numerous group of ground beetles found at the study sites. A higher abundance of carabids was observed in the ARAT and NRAT areas, constituting $21.2 \%$ and $21.9 \%$ of the total number of insect specimens caught, respectively, whereas in the NRAN areas, the share of carabid beetles reached a value of less than $15.0 \%$. Forest species classified as large zoophages and with broad distributions were dominant. Species with moderate humidity requirements and those that prefer moisture-rich habitats were similarly numerous. At each study site, the most numerous carabids were Carabus violaceus (L.) and Pterostichus niger Shaller. Among the captured carabid beetles, C. auronitens Fabr. and C. glabratus Paykull have special protection status in Poland. Interestingly, similarly low values for

Table 5 Summary of GLM analysis of the effect of the soil properties and forest management type on the enzyme activity

\begin{tabular}{llllll}
\hline Effect & $\mathrm{DH}$ & & & $\mathrm{BG}$ & \\
\cline { 2 - 3 } & $F$ & $P$ value & & $F$ & $P$ value \\
\hline Forest management & 1.50 & 0.2424 & & 0.03 & 0.9708 \\
$\mathrm{Ct}$ & $\mathbf{1 8 . 1 9}$ & $\mathbf{0 . 0 0 0 2}$ & & $\mathbf{1 1 . 6 2}$ & $\mathbf{0 . 0 0 2 3}$ \\
Forest management $\times \mathrm{Ct}$ & 2.58 & 0.0962 & & 1.04 & 0.3665 \\
\hline
\end{tabular}

Ct: carbon content; DH: dehydrogenase activity; BG $\beta$-glucosidase activity insect species richness and diversity were found in all the study site types (Table 6).

It was proven that the type of forest regeneration did not significantly influence the epigeic beetle specimens caught in the traps (Mann-Whitney $\mathrm{U}$ test: $Z=1.89 ; p=$ 0.0576). Moreover, a significant difference was found in the number of insect specimens between the managed and unmanaged stands, with the number of insect specimens in the managed stands two and a half times higher than that in the unmanaged study sites (Mann-Whitney $\mathrm{U}$ test: $Z=4.56 ; p=0.0000$ ). When analysing the carabid specimens, statistically significant effects of the type of regeneration (Mann-Whitney $\mathrm{U}$ test: $Z=6.08 ; p=$ 0.0000 ) and management method (Mann-Whitney $\mathrm{U}$ test: $Z=5.09 ; p=0.0000$ ) on abundance were found.

\section{Discussion}

The effect of forest management on the amount of soil organic matter in soils after fires has been proven. Natural stand regeneration was conducive to the accumulation of organic matter. According to Schmidt et al. (1996), intensive soil preparation results in extensive disturbances, which translate into changes in soils, including changes in the amount of soil organic matter. Knicker (2007) and Terefe et al. (2008) claim that changes in the composition and amount of soil organic matter are two of the most common consequences of 
Table 6 Dominance structure, beetles' assemblage indices and the characteristics of Carabids species

\begin{tabular}{|c|c|c|c|c|c|c|c|}
\hline \multirow[t]{2}{*}{ Families/Species } & \multicolumn{4}{|c|}{ Ecological features } & \multicolumn{3}{|c|}{ Variant of the area management } \\
\hline & $A$ & B & C & $\mathrm{D}$ & NRAN & ARAT & NRAT \\
\hline Carabidae & & & & & 14.8 & 21.2 & 21.9 \\
\hline Carabus auronitens Fabr., $1792^{R}$ & $\mathrm{HZ}$ & $\mathrm{F}$ & PA & mez & 0.5 & 0.3 & 0.4 \\
\hline Carabus arcensis Herbst, 1784 & LZ & $\mathrm{F}$ & EU & mez & 0.2 & 0.1 & 0.1 \\
\hline Carabus violaceus L., 1758 & LZ & $E$ & PA & hig & 6.8 & 8.8 & 9.6 \\
\hline Carabus glabratus Paykull, $1790^{R}$ & $\mathrm{HZ}$ & $\mathrm{F}$ & $\mathrm{HA}$ & hig & 0.1 & 2.0 & - \\
\hline Carabus hortensis & $\mathrm{LZ}$ & $\mathrm{F}$ & PA & mez & 0.2 & 0.1 & - \\
\hline Pterostichus niger Shaller, 1783 & LZ & $\mathrm{F}$ & PA & hig & 6.3 & 9.5 & 10.6 \\
\hline Harpalus rufipes De Geer, 1774 & $\mathrm{HZ}$ & O & PA & xer & 0.9 & 0.4 & 1.2 \\
\hline Geotrupidae & & & & & 72.5 & 73.7 & 75.7 \\
\hline Anoplotrupes stercorosus Scriba, 1791 & & & & & 49.2 & 47.7 & 49.4 \\
\hline Trypocopris vernalis L., 1758 & & & & & 23.3 & 26.0 & 26.3 \\
\hline Silphidae & & & & & 0.9 & 2.0 & 1.2 \\
\hline Nicrophorus vespilloides Herbst, 1783 & & & & & 0.9 & 2.0 & 1.2 \\
\hline Cerambycidae & & & & & - & - & 0.1 \\
\hline Stictoleptura rubra & & & & & - & - & 0.1 \\
\hline Curculionidae & & & & & 12.0 & 2.9 & 0.8 \\
\hline Pissodes pini L., 1758 & & & & & 6.3 & 1.0 & 0.2 \\
\hline Hylobius abietis L., 1758 & & & & & 5.7 & 1.9 & 0.6 \\
\hline Number of individuals (pcs.) & & & & & 636 & 692 & 1245 \\
\hline Number of species (pcs.) & & & & & 12 & 12 & 11 \\
\hline Abundance (\%) & & & & & 24.7 & 26.9 & 48.4 \\
\hline Simpson domination (c) & & & & & 0.311 & 0.312 & 0.333 \\
\hline Species diversity of Shannon Weaver $\left(H^{\prime}\right)$ & & & & & 2.170 & 2.135 & 1.972 \\
\hline Simpson's species richness $(D)$ & & & & & 0.687 & 0.686 & 0.666 \\
\hline
\end{tabular}

The superscript "R": rare species included in the Polish Red Data Book of Animals (Głowaciński and Nowacki 2002)

Ecological features: A: trophic group (large zoophages: LZ; small zoophages: SZ; hemizoophages: HZ); B: ecological group (forest species: F; eurytopic species: E; species of open areas: O); C: geographical group (Palaerctic species: PA; Holarctic species: HA; European species: EU); D: environmental humidity preferences (hygrophilous species: hig; mesophilic species: mez; xerophilic species: xer.)

fires. In our research, a significant share of carbon in the surface soil horizons was noted, which indicates the restoration of the humus horizon. During forest fires, temperatures range from 200 to $300^{\circ} \mathrm{C}$. Soil organic matter oxidizes at a temperature of $200{ }^{\circ} \mathrm{C}$ to $315^{\circ} \mathrm{C}$ (Knicker 2007), whereas lignin and hemicellulose degrade at a temperature of $130{ }^{\circ} \mathrm{C}$ to $190{ }^{\circ} \mathrm{C}$ (Chandler et al. 1983). The loss of organic matter as a result of a fire in light soils significantly worsens their sorption ability (Januszek et al. 2001). The nutrients collected in the ash, resulting in a reduced sorption capacity, are quickly exhausted or eluted due to wind or water erosion. The availability of nutrients after a fire is generally higher due to the combustion of organic matter in the soil. In the soils of the post-fire area, regardless of the forest management method, the content of base cations was low. The low content of base cations is a result of elution, which is facilitated by the sandy grains of the soils examined.
To evaluate the microbial activity, the dehydrogenase and $\beta$-glucosidase activities in the soils were investigated. Soil enzyme activities are used as indicators of changes due to their sensitivity to environmental perturbation (Błońska et al. 2017). Dehydrogenase is the most important soil enzyme and is frequently used in determining the influence of various factors on the microbiological quality of soils (Błońska et al. 2016b). In our study, a stimulating role of carbon on the activity of dehydrogenases in the soil was found. The PCA confirmed the positive relationship between dehydrogenase activity and carbon content. Using the GLM, a strong dependence of the enzymatic activity on the soil organic carbon content was observed. Soil enzymes play an important role in the decomposition of organic matter (Aon and Colaneri 2001; Sinsabaugh et al. 2008). Soil microorganisms and their enzymes participate in all the processes associated with the transformation of organic matter in the soil. The results also showed that, regardless of the method 
of stand regeneration, the activity of $\beta$-glucosidase was higher in the post-fire areas with treatment. The breeding treatments may have improved the predominant thermal conditions in the stand as well as the soil cover. The stand in the NRAN area, which was not subjected to any management, was significantly different in terms of structure and characteristics from the remaining stands, which had been treated in the past. According to Wallenstein et al. (2009), temperature and humidity are the basic parameters affecting the enzymatic activity of soils. Variability in $\beta$-glucosidase activity associated with humidity and temperature was noted by Steinweg et al. (2012).

Low levels of polycyclic aromatic hydrocarbons were recorded 23 years after the fire. The sum of the PAHs in the soils of the study areas did not exceed $100 \mu \mathrm{g} \cdot \mathrm{kg}^{-1}$. The threshold values of classification according to Maliszewska-Kordybach (1996) were 200, 600, and $1000 \mu \mathrm{g} \cdot \mathrm{kg}^{-1}$. The studied soils were dominated by the sand fraction, which is not conducive to PAH accumulation. According to Lu et al. (2012), the highest PAH concentration was associated with clay and decreased in the following order: clay $>$ silt $>$ coarse sand $>$ fine sand. The highest content of polycyclic aromatic hydrocarbons was recorded in the soils of the post-fire areas with artificial regeneration. In these soils, five- and six-ring hydrocarbons dominated. These results suggest that the method of preparing the soil before the introduction of new vegetation affects the amount of PAHs.

The forest management strategy also has a significant impact on the epigeic entomofaunal community structure. The highest abundance of captured beetles was found in NRAT and ARAT areas. The managed stands were also characterized by higher predatory carabid abundance in comparison to that in the unmanaged stands, which developed from natural regeneration. As carabid beetles play a crucial role in evaluating the development of forest biocoenoses, we concluded that there were more favourable conditions for tree growth in the treated stands. This seems to confirm the results of the soil analyses and the characteristics of the examined stands. We found that the stand in the NRAN area, which, in its history, has not been subjected to any treatments, significantly and negatively differs in terms of structure relative to the other examined stands and the managed forest model.

The dbh parameter was characterized by a large variation; in the NRAN area, the dbh values were less than half as much as those in the NRAT and ARAT areas. Such a weak increase in tree thickness is caused by a high density during the time when the trees undergo the greatest increase in thickness (Jaworski 2013). A similar pattern was observed for stand height, with the tallest tree predominating the NRAT area, slightly lower trees occurring in the ARAT area, and the shortest trees occurring in the NRAN area. Consequently, the total volume of the stand representing the NRAN area was almost three times lower than that of the stand in the NRAT area, which was characterized by the largest total volume among the examined stands. This phenomenon is undoubtedly related to the difficult growth conditions for the trees in the stands that had not been managed in the past; these growth conditions led to a significant intensification in the trees' inter-individual competition for light, water and nutrients (González de Andrés et al. 2018).

The degree of tree density, regulated by cultivation cuts, directly affects the value of tree growth; achieving maximum growth is possible with the optimal number of trees. Generally, the value of individual trees increases as their density decreases; however, by removing trees, the average growth of the stand decreases (Šmelko et al. 1992). In our study, the stand in the NRAN area was characterized by the highest stand density, a minor increase in the thickness of the trees and the largest number of dying trees in comparison with the stands originating from natural and artificial regeneration. These properties may indicate that the maximum density was reached in the stands in the NRAN area, while the optimal density was reached in the stands in the NRAT and ARAT areas (Bruchwald 1988). Moreover, the high density of trees on the surface of the NRAN stand had a negative impact on the slenderness ratio of the trees, determining their low stability and resistance to abiotic damage. Generally, the larger the growth space, the greater the increase in thickness in relation to the height of a tree, which results in a decrease in the slenderness factor and an increase in stand stability (Baldwin et al. 2000; Kantola and Mäkelä 2004; del Río et al. 2017). Moreover, the initial plant density is crucial for the mean slenderness of trees (Pretzsch and Rai 2016). The value of the slenderness coefficient was relatively low (above 100) for all the study areas, indicating the low stability of the examined stands (Jaworski 2013). However, it is normal for the value of the slenderness factor to exceed 100 in such young stands. In the stand in the NRAN area, where the slenderness factor was 201 , there is extremely low stand stability, which is associated with a very high threat from strong winds and snowfall.

Stand structure parameters have indirect impacts on the ground beetle community. Lange et al. (2014) found a higher number of Carabidae and Staphylinidae ground-dwelling beetle species as well as a higher insects species richness in managed stands relative to that in unmanaged forests. The authors explain this pattern by the higher diversity of vegetation and microhabitat conditions in stands with smaller canopies. Furthermore, 
the authors note that the stand features do not fully explain this phenomenon. Other features, such as soil moisture parameters, should also be taken into account. A negative impact of crown cover on Carabidae diversity and a positive effect of forest management through canopy gap creation were also found by Spake et al. (2016). Jukes et al. (2001) proved that there were negative carabid species richness and diversity relationships with canopy vertical structure and soil organic matter. Surprisingly, we did not confirm this pattern, as the managed and unmanaged stands presented similarly low species richness and diversity. These contrasting results might have consequences at the regional level in our study (Fuller et al. 2008). Many ground-dwelling species are characterized by different regional habitat preferences (Gossner et al. 2014); thus, studies in different regions make it difficult to draw clear conclusions about forest management strategy impacts (Koivula 2012). Nevertheless, the NRAT stand, characterized by the highest tree height and diameter among all the analysed stand types, presented the highest number of insects overall and carabid species. Barkley et al. (2016) confirmed a strong dependence of the carabid community on stem diameter, reporting carabid specimens more frequent from stands with high tree canopy heights, large trees and high vertical foliage complexity.

Based on the obtained results, the natural regeneration of forests with management practices is considered the best reforestation method, since it creates the ideal conditions for the natural processes occurring in forest ecosystems.

\section{Conclusions}

Our findings underline the importance of a multifactorial approach to understanding the process of restoring forest ecosystems after wildfires. The field experiments provided evidence that forest management influences soil properties to a small extent, while having an important impact on ground beetle communities. As expected, the enzymatic activity of soils was affected by the renewal method and forest management strategy. The results suggest that the method of preparing the soil before the introduction of new vegetation affects the carbon content in the soil. The better performance of the stand in the NRAT area indicates the positive influence of natural regeneration from an ecological and economic point of view. Further studies are needed to monitor soil changes during the restoration process. Considering the characteristics of the soils, the value of human intervention in natural regeneration processes has not been proven. Nevertheless, bearing in mind the strong effect of forest management type on forest structure and epigeic beetle assemblages, intervention in the natural regeneration processes of pioneer species growing in post- fire areas may be considered appropriate human action. Forests are increasingly affected by climate change and are thus vulnerable to fires. The obtained results suggest that natural regeneration with management practices is the most reasonable method for managing forests after fires. This method for managing forest areas ensures the maintenance of correct soil conditions and the biodiversity of the forest ecosystem.

\begin{abstract}
Abbreviations
ARAT: Artificial Renewed Area with Treatment; BG: $\beta$-glucosidase activity; dbh: the diameter at breast height; DH: Dehydrogenase activity; E: Eurytopic species; EU: European species; F: Forest species; G: Stand basal area; H: Lorey height; H/D: Slenderness coefficient; HA: Holarctic species; Hig: Hygrophilous species; HZ: Hemizoophages; LZ: Large zoophages; Mez: Mesophilic species; N: Number of trees per hectare; NRAN: Natural Renewed Area with No treatment; NRAT: Natural Renewed Area with Treatment; O: Species of open areas; PA: Palaerctic species; SZ: Small zoophages; V: Stand volume;

Xer: Xerophilic species
\end{abstract}

\section{Acknowledgements}

The authors thank Jakub Pietrzak and Weronika Szaflik for their help in the field study. We also thank Piotr Kościelniak from Jagiellonian University, Faculty of Mathematics and Computer Science, Institute of Mathematics, Department of Applied Mathematics, Krakow, for the statistical analyses performed in R software.

\section{Authors' contributions}

$\mathrm{EB}, \mathrm{BB}$ designed the experiment and implemented the study, with assistance from MK and JL. All authors analysed the results and contributed to the manuscript writing and editing. All authors read and approved the final manuscript.

\section{Funding}

This work was supported by the Ministry of Science and Higher Education of the Republic of Poland.

\section{Availability of data and materials}

Data available on request from the authors.

Ethics approval and consent to participate

The subject has no ethic risk.

Consent for publication

Not applicable.

\section{Competing interests}

The authors declare that they have no competing interests.

\section{Author details}

${ }^{1}$ Department of Ecology and Forest Silviculture, Faculty of Forestry, University of Agriculture in Krakow, Al. 29-go Listopada 46, 31-425 Kraków, Poland.

${ }^{2}$ Department of Forest Ecosystems Protection, Faculty of Forestry, University of Agriculture in Krakow, Al. 29-go Listopada 46, 31-425 Kraków, Poland.

Received: 27 December 2019 Accepted: 7 April 2020

Published online: 26 April 2020

\section{References}

Alef K, Nannipieri P (1995) Enzyme activities. In: Alef K, Nannipieri P (eds) Methods in applied soil microbiology and biochemistry. Academic Press, London

Aon MA, Colaneri AC (2001) Temporal and spatial evolution of enzymatic activities and physic-chemical properties in an agricultural soil. Appl Soil Ecol 18:255-270. https://doi.org/10.1016/50929-1393(01)00161-5

Baldwin VC, Peterson KD, Clark A, Ferguson RB, Strub MR, Bower DR (2000) The effects of spacing and thinning on stand and tree characteristics of 38-yearold loblolly pine. Forest Ecol Manage 137:91-102. 
Barkley E, Malcolm JR, Smith SM, Bellocq MI (2016) Does variable stand structure associated with multi-cohort forests support diversity of ground beetle (Coleoptera, Carabidae) communities in the central Nearctic boreal forest? J Forest Res 27(5):1191-1202. https://doi.org/10.1007/s11676-016-0252-z

Barros AMG, Ager AA, Day MA, Krawchuk MA, Spies TA (2018) Wildfires managed for restoration enhance ecological resilience. Ecosphere. https://doi.org/10. 1002/ecs2.2161

Beaudry S, Duchesne LC, Côté B (1997) Short-term effects of three forestry practices on carabid assemblages in a jack pine forest. Can J For Res 27(12): 2065-2071. https://doi.org/10.1139/×97-171

Błońska E, Lasota J, Gruba P (2017) Enzymatic activity and stabilization of organic matter in soil with different detritus inputs. J Soil Sci Plant Nutr 63:242-247. https://doi.org/10.1080/00380768.2017.1326281

Błońska E, Lasota J, Szuszkiewicz M, Łukasik A, Klamerus-Iwan A (2016a) Assessment of forest soil contamination in Krakow surroundings in relation to the type of stand. Environ Earth Sci 75(16):1-15. https://doi.org/10.1007/ s12665-016-6005-7

Błońska E, Lasota J, Zwydak M, Klamerus-Iwan A, Gołąb J (2016b) Restoration of forest soil and vegetation 15 years after landslides in a lower zone of mountains in temperate climates. Ecol Eng 97:503-515. https://doi.org/10. 1016/j.ecoleng.2016.10.068

Brais S, David P, Ouimer R (2000) Impats of wild fire severity and salvage harvesting on the nutrient balance of jack pine and black spruce boreal stands. Forest Ecol Manag 137:231-243

Bruchwald A (1988) Przyrodnicze podstawy budowy modeli wzrostu (natural bases for construction of growth models). Sylwan 132(11/12):1-10

Burakowski B, Mroczkowski M, Stefańska J (1974) Chrząszcze - Coleoptera. Biegaczowate - Carabidae część 2. Katalog Fauny Polskiej (Beetles Coleoptera. Carabidae part 2. Polish Fauna Catalog) 23(3):1-430 (in Polish)

Certini G (2005) Effects of fire on properties of forest soils: a review. Oecol 143:110. https://doi.org/10.1007/s00442-004-1788-8

Chandler C, Cheney P, Thomas P, Trabaud L, Williams D (1983) Fire in forestry: Forest fire behavior and effects. Wiley, New York

de Jong Y, Verbeek M, Michelsen V, de Place BP, Los W, Steeman F, Bailly N, Basire C, Chylarecki P, Stloukal E, Hagedorn G, Wetzel FT, Glöckler F, Kroupa A, Korb G, Hoffmann A, Häuser C, Kohlbecker A, Müller A, Güntsch A, Stoev P, Penev L (2014) Fauna Europaea - all European animal species on the web. Biodivers Data J 2:e4034. https://doi.org/10.3897/BDJ.2.e4034 Accessed 27 Nov 2019

DeBano FL, Neary DG, Ffolliott PF (1998) Fire's effects on ecosystems, 1st edn. Wiley, New York

del Río M, Bravo-Oviedo A, Pretzsch H, Löf M, Ruiz-Peinado R (2017) A review of thinning effects on scots pine stands: from growth and yield to new challenges under global change. Forest Syst. https://doi.org/10.5424/fs/ 2017262-11325

Dziadowiec $\mathrm{H}$ (2010) The influence of forest fire on the properties of forest soils In: Sewerniak P, Gonet SS (eds) Environmental effects of Forest fire. Polish Society of Humic Substances, Wrocław

Eivazi F, Tabatabai MA (1990) Factors affecting glucosidase and galactosidase activity in soils. Soil Biol Biochem 22:891-897. https://doi.org/10.1016/00380717(90)90126-K

FAO (1998) FAO Meeting on Public Policies Affecting Forest Fires. FAO Forestry Paper No. 138, Rome

Francos M, Pereira P, Mataix-Solera J, Arcenequi V, Alcaniz M, Ǔbeda X (2018) How clear-cutting affects fire severity and soil properties in a Mediterranean ecosystem. J Environ Manag 206:625-632

Fuller RJ, Oliver TH, Leather SR (2008) Forest management effects on carabid beetle communities in coniferous and broadleaved forests: implications for conservation. Insect Conserv Diver 1(4):242-252. https://doi.org/10.1111/j. 1752-4598.2008.00032.x

Głowaciński Z, Nowacki J (2002) The polish red data book of animals. Institute of Nature Conservation. Polish Academy of Sciences, Krakow

Gonet SS (2010) The influence of forest fire on the properties of organic matter of soils. In: Sewerniak P, Gonet SS (eds) Environmental effects of forest fire. Polish Society of Humic Substances, Wrocław

Gongalsky KB, Midtgaard F, Overgaard HJ (2006) Effects of prescribed forest burning on carabid beetles (Coleoptera: Carabidae): a case study in SouthEastern Norway. Entom Fenn 17:325-333. https://doi.org/10.33338/ef.84352

González de Andrés E, Camarero JJ, Blanco JA, Imbert JB, Lo Y-H, SangüesaBarreda G, Castillo FJ (2018) Tree-to-tree competition in mixed European beech-scots pine forests has different impacts on growth and water-use efficiency depending on site conditions. J Ecol 106:59-75. https://doi.org/10. 1111/1365-2745.12813

González-Pérez JA, González-Vila FJ, Almendros G, Knicker H (2004) The effect of fire on soil organic matter-a review. Environ Int 30:855-870. https://doi.org/ 10.1016/j.envint.2004.02.003

Gossner MM, Fonseca CR, Pašalić E, Türke M, Lange M, Weisser W (2014) Limitations to the use of arthropods as temperate forests indicators. Biodivers Conserv 23(4):945-962. https://doi.org/10.1007/s10531-014-0644-3

Hawryś Z, Zwoliński J, Matuszczyk I, Olszowska G, Zwolińska B, Batko B (1998) Changes and restoration of forest ecosystems destroyed by fire on the example of a large-scale fire in the Rudzko-Rudziniecko-Kędzierzyńskie forests. Adv Forest Technol 67:33-40. https://doi.org/10.2478/v10111-0090018-x

Holliday NJ (1991) Species responses of carabid beetles (Coleoptera: Carabidae) during post-fire regeneration of boreal forest. Can Entomol 123(6):1369-1389. https://doi.org/10.4039/Ent1231369-6

Homann PS, Bormann BT, Darbyshire RL, Morrissette BA (2011) Forest soil carbon and nitrogen losses associated with wildfire and prescribed fire. Soil Sci Soc Am J 75:1926-1934

Hưrka K (1996) Carabidae of the Czech and Slovak Republices. Kabourek Press, Zlin

Januszek K, Lasota J, Gruba P, Domicz G (2001) Physico-chemical and biochemical properties of podzolic soils six years after the forest fire. Acta Agraria Silvestria Ser Silvestris 39:47-61

Jaworski A (2013) Hodowla lasu. Pielęgnowanie lasu (Forest silviculture. Intermediate treatments) (Polish Edition). PWRiL, Warsaw

Jukes MR, Peace AJ, Ferris R (2001) Carabid beetle communities associated with coniferous plantations in Britain: the influence of site, ground vegetation and stand structure. For Ecol Manag 148(1-3):271-286. https://doi.org/10.1016/ S0378-1127(00)00530-2

Kaczmarek Z, Michalik J, Spychalski W (2004) Selected chemical properties and content of water soluble constituents of forest soils in Potrzebowice post-fire area in relation to the method of reclamation. Soil Sci Annu 55(2):201-208

Kantola A, Mäkelä A (2004) Crown development in Norway spruce [Picea abies (L. ) Karst.]. Trees 18:408-421. https://doi.org/10.1007/s00468-004-0319-x

Kazakevič AL, Černov Al, Bobrov AA, Trofimov SA (1998) Vlijane lokalnogo nizowogo pozara na počvennyj pokrov elnikov (na primere CentralnoLesnogo Biosfernogo Zapovednika) (The effect of local grassrot fire on spruce in soil cover (on the example of Central-Forest State natural Biosphere Reserve)). Lesovedenie 6:42-54 (in Russian)

Klausnitzer B (2005) Käfer. 2 Auflage: überarb (Beetles. 2nd edition: revised). Nikol, Hamburg (in German)

Knicker $\mathrm{H}$ (2007) How does fire affect the nature and stability of soil organic nitrogen and carbon? A review. Biogeochemistry 85:91-118. https://doi.org/ 10.1007/s10533-007-9104-4

Koivula MJ (2011) Useful model organisms, indicators, or both? Ground beetles (Coloptera, Carabidae) reflecting environmental conditions. ZooKeys 100: 287-317. https://doi.org/10.3897/zookeys.100.1533

Koivula MJ (2012) Under which conditions does retention harvesting support ground beetlesof boreal forests? Baltic J Coleopterol 12(1):7-26

Kubicz J, Kajewski I, Kajewska-Szkudlarek J, Dębek PB (2019) Ground-water recharge assessment in dry years. Environ Earth Sci 78:555

Kundzewicz ZW, Matczak P (2012) Climate change region al review: Poland. Wiley Interdiscip Rev Clim Chang 3(4):297-311

Lange $M$, Türkea M, Pašalić E, Boch S, Hessenmöller D, Müller J, Prati D, Socher SA, Fischer M, Weisser WW, Gossner MM (2014) Effects of forest management on ground-dwelling beetles (Coleoptera; Carabidae, Staphylinidae) in Central Europe are mainly mediated by changes in forest structure. Forest Ecol Manag 329:166-176. https://doi.org/10.1016/j.foreco.2014.06.012

Lu Z, Zeng F, Xue N, Li F (2012) Occurrence and distribution of polycyclic aromatic hydrocarbons in organo-mineral particles of alluvial sandy soi profiles at a petroleum-contaminated site. Sci Total Environ 433:50-57. https://doi.org/10.1016/j.scitotenv.2012.06.036

Maliszewska-Kordybach B (1996) Polycyclic aromatic hydrocarbons in agricultural soils in Poland: preliminary proposals for criteria to evaluate the level of soil contaminations. Appl Geochem 11:121-127. https://doi.org/10.1016/08832927(95)00076-3

Martìnez-Sánchez JJ, Ferrandis P, de las Heras J, Herranz JM (1999) Effect of burnt wood removal on the natural regeneration of Pinus halepensis after fire in a pine forest in Tus valley (SE Spain). Forest Ecol Manag 123:1-10

Ochał W (1999) Volume tables of standing trees, beta version 1.0. MS windows application. Department of Biometry and Productivity of the Forest Institute 
of Forest Resources Management, Faculty of Forestry, University of Agriculture in Krakow, Krakow

Operat siedliskowy dla Nadleśnictwa Rudy Raciborskie (2005) Biuro Urządzania Lasu i Geodezji Leśnej. w Krakowie (in Polish)

Piwnicki J, Ubysz B (2004) Large-area forest fires. Forest Research Institute, Warszawa

Pretzsch H, Rai A (2016) Wood quality in complex forests versus even-aged monocultures: review and perspectives. Wood Sci Technol 50:845-880. https://doi.org/10.1007/s00226-016-0827-z

Pritchett WL, Fisher RF (1987) Properties and management of forest soils, 2nd edn. Wiley, New York

R Development Core Team (2017) R: a language and environment for statistical computing, reference index version 2.2.1. R Foundation for Statistical Computing, Vienna http://www.R-project.org. Accessed 27 Nov 2019

Schmidt MG, Macdonald SE, Rothwell RL (1996) Impacts of harvesting and mechanical site preparation on soil chemical properties of mixed-wood boreal forest sites in Alberta. Can J Soil Sci 6:531-540. https://doi.org/10. 4141/cjss96-066

Shannon CE, Weaver W (1948) The mathematical theory of communication. University of Illinois Press, Urbana

Simpson EH (1949) Measurement of diversity. Nature. https://doi.org/10.1038/ $163688 \mathrm{a} 0$

Sinsabaugh RL, Lauber CL, Weintraub MN, Ahmed B, Allison SD, Crenshaw C, Contosta AR, Cusack D, Frey S, Gallo ME, Gartner TB, Hobbie SE, Holland K, Keeler BL, Powers JS, Stursova M, Takacs-Vesbach C, Waldrop MP, Wallenstein MD, Zak DR, Zeglin LH (2008) Stoichiometry of soil enzyme activity at global scale. Ecol Lett 11:1252-1264. https://doi.org/10.1111/j.1461-0248.2008.01245.x

Skłodowski J (1994) Wpływ pożarów o różnej intensywności na zgrupowania biegaczowatych (Coleoptera, Carabidae) zamieszkujących drzewostany sosnowe w różnym wieku. (influence of fires of varying intensity on the grouping Carabid beetles living in pine stands of various ages). Sylwan 12: 131-144 (in Polish)

Skłodowski J, Bajor P, Trynkos M (2018) Carabids benefit more from pine stands with added understory or second story of broad-leaved trees favored by climate change than from one-storied pine stands. Eur J For Res 137(5):745757. https://doi.org/10.1007/s10342-018-1137-9

Skłodowski J, Garbalińska P (2007) Ground beetle assemblages (Coleoptera, Carabidae) in the third year of regeneration after a hurricane in the Puszcza Piska pine forests. Baltic J Col 7(1):17-36

Šmelko S, Wenk G, Antaniatis V (1992) Rast, štruktura a produkcia lesa (growth, structure and production of wood). Priroda, Bratislava (in Slovak)

Spake R, Barsoum N, Newton AC, Doncaster CP (2016) Drivers of the composition and diversity of carabid functional traits in UK coniferous plantations. For Ecol Manag 1(359):300-308. https://doi.org/10.1016/j.foreco.2015.10.008

StatSoft, Inc. (2010 STATISTICA version 10.0). Computer software.

Steinweg JM, Dukes JS, Wallestein MD (2012) Modeling the effects of temperature and moisture on soil enzyme activity: linking laboratory assays to continuous field data. Soil Biol Biochem 55:85-92

Stoddard MT, Huffman DW, Fulé PZ, Crouse JE, Sánchez Meador AJ (2018) Forest structure and regeneration responses 15 years after wildfire in a ponderosa pine and mixed-conifer ecotone, Arizona, USA. Fire Ecol. https://doi.org/10. 1186/s42408-018-0011-y

Szczygieł R (2012) Wielkoobszarowe pożary lasów w Polsce (Large-area forest fires in Poland). Safe Fire Technol 25(1):67-78 (in Polish)

Terefe T, Mariscal-Sancho I, Peregrina F, Espejo R (2008) Influence of heating on various properties of six Mediterranean soils. A laboratory study. Geoderma 143:273-280. https://doi.org/10.1016/.jgeoderma.2007.11.018

Trautner J, Geigenmüller K (1987) Illustrated key to the Cicindelidae and Carabidae of Europe. Josef Margraf Publisher, Aichtal

Ubysz B, Szczygieł R, Piwnicki J (2006) Analysis of the trends in the forest fire risk for recent years in Poland against the background of long-term trends. Forest Ecol Manag. https://doi.org/10.1016/j.foreco.2006.08.277

Verma S, Jayakumar S (2012) Impact of forest fire on physical, chemical and biological properties of soil: a review. Proceed Int Acad Ecol Environ Sci 2(3): 168-176

Wallenstein MD, McMahon SK, Schimel JP (2009) Seasonal variation in enzyme activities and temperature sensitivities in Arctic tundra soils. Glob Chang Biol 15:1631-1639

Wikars L-O (1997) Effects of forest fire and the ecology of fire-adapted insects. Uppsala University, Sweden, Dissertation
Xue L, Li Q, Chen H (2014) Effects of a wildfire on selected physical, chemical and biochemical soil properties in a Pinus massoniana forest in South China. Forests 5:2947-2966. https://doi.org/10.3390/f5122947

\section{Submit your manuscript to a SpringerOpen ${ }^{\circ}$ journal and benefit from:}

- Convenient online submission

- Rigorous peer review

- Open access: articles freely available online

High visibility within the field

- Retaining the copyright to your article

Submit your next manuscript at $\boldsymbol{\nabla}$ springeropen.com 